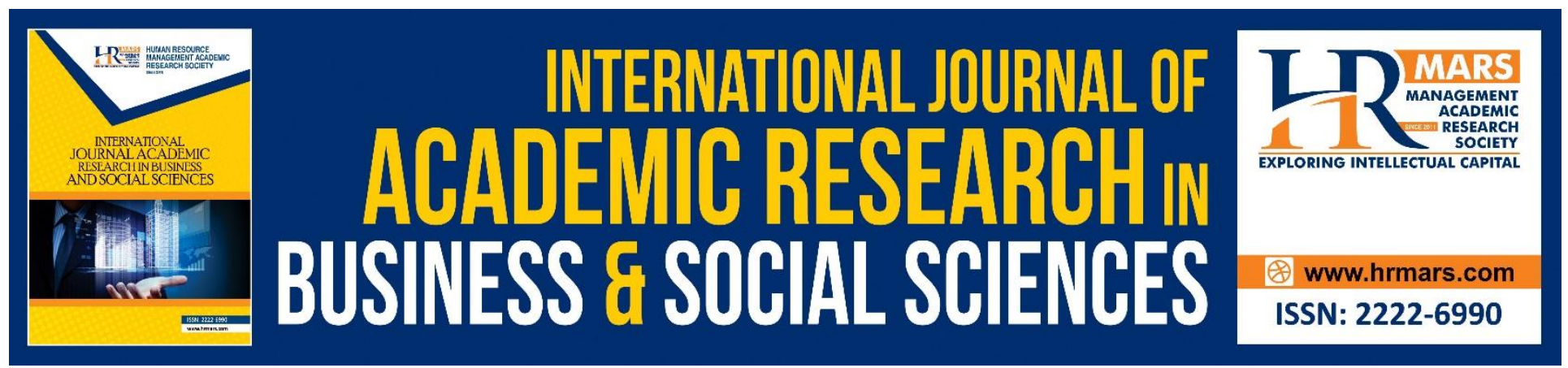

\title{
Critical Success Factor for Sustainable Facilities Management: A Review of Literature
}

\author{
Intan Bayani Zakaria, Siti Zubaidah Hashim, Nadira Ahzahar
}

To Link this Article: http://dx.doi.org/10.6007/IJARBSS/v8-i7/4388

DOI: $\quad 10.6007 /$ IJARBSS/v8-i7/4388

Received: 28 May 2018, Revised: 19 June 2018, Accepted: 29 June 2018

Published Online: 18 July 2018

In-Text Citation: (Zakaria, Hashim, \& Ahzahar, 2018)

To Cite this Article: Zakaria, I. B., Hashim, S. Z., \& Ahzahar, N. (2018). Critical Success Factor for Sustainable Facilities Management: A Review of Literature. International Journal of Academic Research in Business and Social Sciences, 8(7), 469-480.

Copyright: (C) 2018 The Author(s)

Published by Human Resource Management Academic Research Society (www.hrmars.com)

This article is published under the Creative Commons Attribution (CC BY 4.0) license. Anyone may reproduce, distribute, translate and create derivative works of this article (for both commercial and non-commercial purposes), subject to full attribution to the original publication and authors. The full terms of this license may be seen

at: http://creativecommons.org/licences/by/4.0/legalcode

Vol. 8, No. 7, July 2018, Pg. 469 - 480

http://hrmars.com/index.php/pages/detail/IJARBSS

JOURNAL HOMEPAGE

Full Terms \& Conditions of access and use can be found at http://hrmars.com/index.php/pages/detail/publication-ethics 


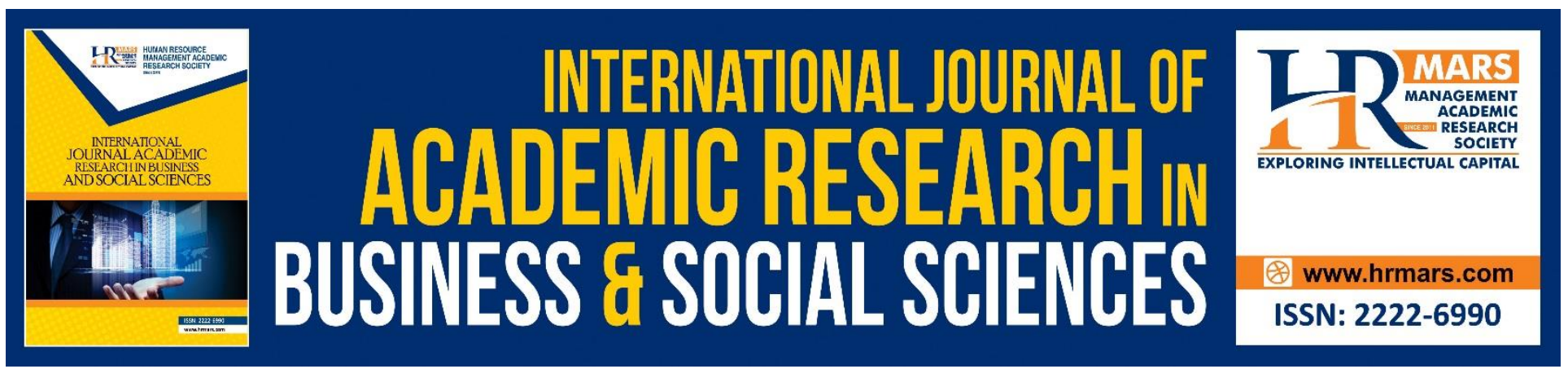

\title{
Critical Success Factor for Sustainable Facilities Management: A Review of Literature
}

\author{
Intan Bayani Zakaria, Siti Zubaidah Hashim, Nadira Ahzahar \\ Faculty of Architecture, Planning and Surveying, Universiti Teknologi MARA (Perak Branch), \\ Malaysia
}

\begin{abstract}
Effort to sustainable facilities management (SFM) requires a paradigm shift in terms of management, technology adoption and end-user behaviors. In order to achieve the above efforts, the main role that the FM profession can play is by encouraging management hierarchy in the organization and end users to understand the importance and impact of sustainable development. At the same time, FM professions need to be proactive and be a good role model in managing the facilities and services of a building. According to previous research, the sustainable facilities management process and practices are unclear and immature. Therefore, the objective of this study is to identify and compile critical success factors in order to give a positive impact on implementing SFM, as per the literature. The study used content analysis method with frequency analysis. Nineteen success factors were identified. The most common identified success factors in the literature are strict legislation set by the government, organization's sustainability policy, the commitment and the perception of practicing facilities manager, the involvement of senior management personnel and organizations should provide training and practical management tools for facilities managers. One of the future research can aim towards conducting a severity analysis of the identified factors with regard to the facilities management industry.
\end{abstract}

Keywords: Sustainable Development, Facilities Management, Sustainable Facilities Management, Critical Success Factor

\section{Introduction}

\section{Sustainable Development}

According to a report conducted by Brundtland Commission(WCED,1987), sustainable development is defined as "development which meets the needs of the present without compromising the ability of future generations to meet their own needs." Another researcher mentioned that focal point of sustainability is the integration of economic, social and environmental development as the triple bottom line for sustainable development (Elmualim et al.,2009). Although there are many different definitions, there is a shared theme of environment, future and equality. In consideration of sustainability aspect, it guides us to make improvements to our daily activities, business decisions, 
INTERNATIONAL JOURNAL OF ACADEMIC RESEARCH IN BUSINESS AND SOCIAL SCIENCES Vol. 8, No. 7, July 2018, E-ISSN: 2222-6990 @ 2018 HRMARS

and future planning by taking into account the contribution of the activity to the economy, the social and the environment. The incorporation of sustainable development in the day-to-day functions of facilities management is not new; the business world has also seen that with the adaptation of green sustainability it has added a competitive edge to the global market (Vidler,2011).

According to Shah (2007), the primary focus for facilities managers now is to provide added value as part of the management of their property by identifying environmental costs and business opportunities but in the other hand, it has previously been observed that there is lack of skills, knowledge and tools within the Facilities Management industry to manage facilities from a sustainability perspective actively (Elmualim, 2012a; Escriva-Escriva, 2011). These problems protrude the basis of this study.

\section{Facilities Management}

The concept of facility management (FM) is a combination of non-core organization services involving mainly the maintenance of buildings. The existence of this facility management is intended to assist and support the core business of an organization. The main factors involved in managing sustainable facilities include management, technology applications and end-users. Effective building maintenance methods will contribute to improving building performance. For example, good energy management in the building can reduce carbon dioxide emissions and at the same time preserve the environment (Escriva-Escriva, 2011).

Looking at the above this clearly shows that FM plays an essential role in delivering a sustainable environment as expected by the end user company (Nousiainen and Junnila, 2008). Sustainable Facilities Management (SFM) is critical because a building is the highest consumer of energy ( Suzuki and Oka, 1998) during operation and involves the generation of waste from indoor activities. FMrelated management costs are the second largest operating cost after personnel and asset costs. Therefore, effective FM management can reduce overall cost burden.

\section{Sustainable Facilities Management}

FM has long established and expanded in Japan, Hong Kong, New Zealand, Singapore and South Africa. FM's most significant contribution to the organization is to assist building management in a more efficient direction while directly supporting the core business of the organization (Kamaruzzaman and Zawawi, 2010). According to Shah (2007) in Australia, the FM industry recorded an annual turnover of more than AUD\$60 billion which is now a major trending business in the country. For other developing countries such as Malaysia, FM only began to lay the foundations during the second half of the 1990s and now FM development has already started to be given particular focus especially FM in the public sector (Kamaruzzaman and Zawawi, 2010).

The effort in sustainability requires a paradigm shift in terms of management, technology adoption and end-user behaviors (Elmualim et al., 2009). In order to achieve the above target, the central role that the FM profession can play is by encouraging management hierarchy in the organization and end users to understand the importance and impact of sustainable development (Shah, 2007). At the same time, FM professions need to be proactive and be a good role model for managing the facilities and services in the building. 
INTERNATIONAL JOURNAL OF ACADEMIC RESEARCH IN BUSINESS AND SOCIAL SCIENCES Vol. 8, No. 7, July 2018, E-ISSN: 2222-6990 @ 2018 HRMARS

In order to make a precise dimension on sustainability in facilities management, Prof. Dr.-Ing. Antje Junghans had produced a basic structure of Sustainable Facility Management known as SFM-Model (Fig.1). The category includes primary ]processes, space and infrastructure, people and organization. Dimension and target of sustainability are shown in Table 1.

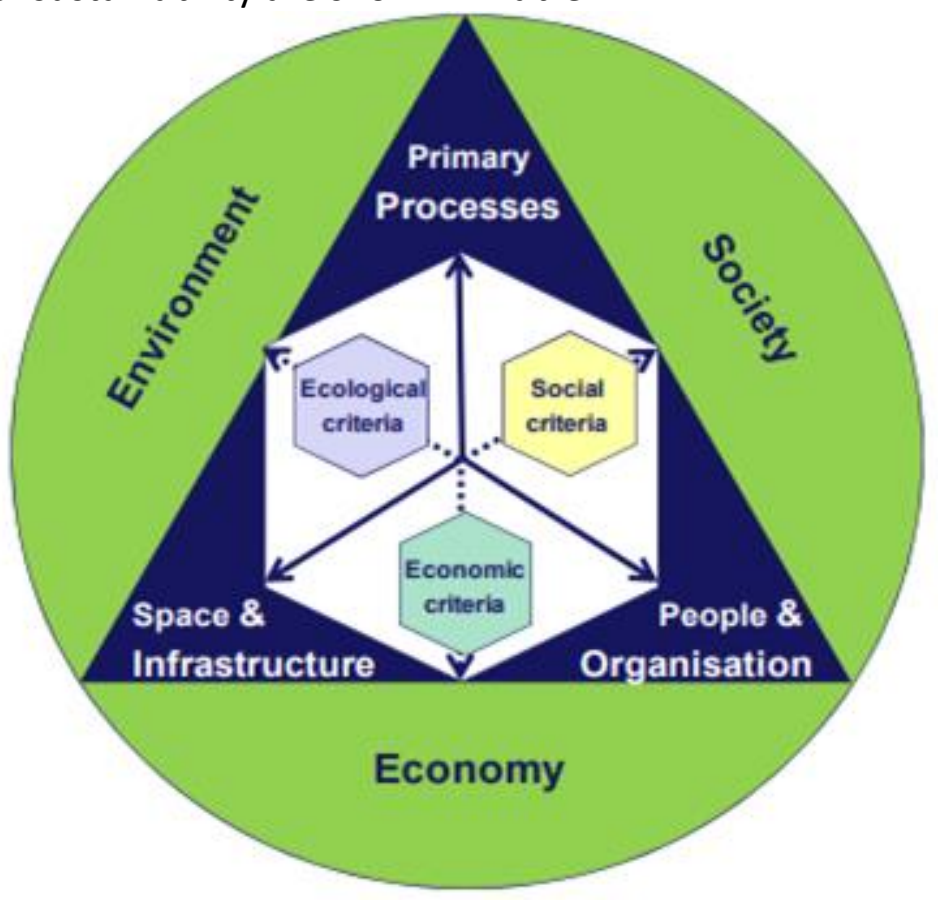

Fig. 1. The SFM model (Jughans,2011)

Table 1: Dimension and target of sustainability 
INTERNATIONAL JOURNAL OF ACADEMIC RESEARCH IN BUSINESS AND SOCIAL SCIENCES Vol. 8, No. 7, July 2018, E-ISSN: 2222-6990 @ 2018 HRMARS

\begin{tabular}{|c|c|}
\hline Dimensions of sustainability & Target \\
\hline Social & $\begin{array}{l}\text { - } \text { supply of adequate buildings for work and life; } \\
\text { - compliance with health, safety and security requirements. }\end{array}$ \\
\hline Environment & $\begin{array}{l}\text { - } \text { reduction of resources; } \\
\text { - usage of recyclable building material; considering the } \\
\text { separability of used material for re-use; reduction of energy } \\
\text { consumption and usage of renewable energy sources; } \\
\text { - reduction of space requirements and soil sealing; } \\
\text { safeguarding the ability to maintain and de-construct } \\
\text { buildings; } \\
\text { - preventing the usage of material causing excessive emissions }\end{array}$ \\
\hline Economy & $\begin{array}{l}\text { - building space optimization for a most efficient usage; } \\
\text { - } \quad \text { optimization of building life-cycle costs; } \\
\text { - facilitating the most efficient management methods. }\end{array}$ \\
\hline
\end{tabular}

In a study conducted by Jensen and Maslesa (2015) and Store-Valen and Jardar (2016) found that there was an inability among FM practitioners in determining effective value management and weaknesses addressing service requirements for the end user. According to Buser (2017) found that there was a lack of awareness of practical values among FM practitioners that could lead to sustainable change which has been viewed as potential personnel that can drive towards the sustainable agenda.

Increased recognition of the need to manage sustainable facilities are seen to be catalyzed by FM practitioners and can be seen as a source of pressure for facility managers to prove FM strategic values to their organizations. In Malaysia,this recognition is still unclear as FM practice towards sustainable is still immature and focuses on the field of building operations only (Baaki et al., 2016). So there is a need to study the critical success factor (CSF) that contributes to the sustainable facilities management. This CSF can assist the sustainable agenda in facilities management to grow.

\section{Critical Success Factor}

CSFs are defined as "those few key areas where things must go right for a business to grow or necessary for a manager to reach his/her goals" (Rockart,1982). Based on this definition, if the 
INTERNATIONAL JOURNAL OF ACADEMIC RESEARCH IN BUSINESS AND SOCIAL SCIENCES

Vol. 8, No. 7, July 2018, E-ISSN: 2222-6990 @ 2018 HRMARS

facilities management does not pay attention to these areas the performance will not lead to sustainable. The CFS assessment methods have been exploring in different areas of sustainable and have confirmed CFS's interest in improved performance.

This paper is organized as follows. Section 2 describes the methodology. Sections 3 describe the CSFs as identified by the literature. Section 4 concludes this paper.

\section{Methodology}

The objective of this study is to identify what factors that have a positive impact on implementing SFM and compiled profiling of success factor associated with SFM implementation, as per literature. For the study, the keywords utilized during the search were SFM's key success factors, SFM drivers, implementation, and issues. With the help of keywords, a total of 60 publications were identified. This list of publications is selected by taking into account studies that contribute towards the objective of the study for further analysis.

In order to analyze the factors, the frequency analysis technique and was used to measure the occurrence of success factors. The occurrence of a success factor in each article has been noted. With a frequency analysis, it shows the frequency with which a success factor appears in the literature. For each factor, the actual number of occurrences is determined, as is the percentage of scenes in the sample that the number represents. For example, the percentage $x$ for factor $y$ means the number of times the $\mathrm{y}$ factor is mentioned in $\mathrm{x} \%$ literature, i.e., if a factor mentioned is in 5 out of 10 articles, this means it has a $50 \%$ interest for comparison purposes. In this way, the factors are being compared and ranked. Finally, conclusions are drawn regarding towards the factors that are critical in the literature.

\section{Results}

Tables 2 show the CSFs cited in the literature and the frequency with which they occurred. The percentage shows the proportion of literature that cited a particular CSF.

CSFs identified during 2000 - to date

Table 2 shows the list of CSFs cited in the Literature. CSFs are listed in order of their importance.

\begin{tabular}{|c|c|c|c|c|}
\hline \multirow[t]{2}{*}{ No. } & \multirow[t]{2}{*}{$\begin{array}{l}\text { Critical success factors in } \\
\text { literature }\end{array}$} & \multirow[t]{2}{*}{ Referenced in } & \multicolumn{2}{|c|}{$\begin{array}{l}\text { Occurrence in literature } \\
\qquad(n=19)\end{array}$} \\
\hline & & & Freq. & $\%$ \\
\hline 1 & $\begin{array}{l}\text { Proper planning especially } \\
\text { as knowing the long-term } \\
\text { costs }\end{array}$ & $\begin{array}{l}\text { Asbollah et al.(2016), } \\
\text { Ikediashi et al. (2014) }\end{array}$ & 2 & 11 \\
\hline
\end{tabular}


INTERNATIONAL JOURNAL OF ACADEMIC RESEARCH IN BUSINESS AND SOCIAL SCIENCES Vol. 8, No. 7, July 2018, E-ISSN: 2222-6990 @ 2018 HRMARS

\begin{tabular}{|c|c|c|c|c|}
\hline 2 & $\begin{array}{l}\text { The methodology of } \\
\text { managing physical assets }\end{array}$ & Asbollah et al.(2016) & 1 & 5 \\
\hline 3 & $\begin{array}{l}\text { Organization's } \\
\text { sustainability policy }\end{array}$ & $\begin{array}{l}\text { Buser (2017), Baaki et } \\
\text { al. (2016), Ikediashi et } \\
\text { al. (2014) Adewunmi } \\
(2012)\end{array}$ & 4 & 21 \\
\hline 4 & $\begin{array}{l}\text { Strict legislation set by the } \\
\text { government }\end{array}$ & $\begin{array}{l}\text { Buser (2017), Baaki et } \\
\text { al. (2016), } \\
\text { Collins and Junghans } \\
\text { (2015), Ikediashi et al. } \\
\text { (2014), } \\
\text { Meng (2014), Elmualim } \\
\text { et al. (2012a) }\end{array}$ & 6 & 32 \\
\hline 5 & Sustainable FM strategy & Baaki et al. (2016) & 1 & 5 \\
\hline 6 & $\begin{array}{l}\text { Highly qualified technical } \\
\text { professionals }\end{array}$ & $\begin{array}{l}\text { Meng (2014), } \\
\text { Elmualim et al. (2010) }\end{array}$ & 2 & 11 \\
\hline 7 & $\begin{array}{l}\text { The commitment and the } \\
\text { perception of practicing } \\
\text { facilities manager }\end{array}$ & $\begin{array}{l}\text { Buser (2017), } \\
\text { Meng (2014), Elmualim } \\
\text { et al. (2010) }\end{array}$ & 3 & 16 \\
\hline 8 & $\begin{array}{l}\text { Integration of FM within } \\
\text { the strategic management } \\
\text { function }\end{array}$ & $\begin{array}{l}\text { Adewunmi et al. (2012), } \\
\text { Elmualim et al. (2010) }\end{array}$ & 2 & 11 \\
\hline
\end{tabular}


INTERNATIONAL JOURNAL OF ACADEMIC RESEARCH IN BUSINESS AND SOCIAL SCIENCES Vol. 8, No. 7, July 2018, E-ISSN: 2222-6990 @ 2018 HRMARS

\begin{tabular}{|c|c|c|c|c|}
\hline 9 & $\begin{array}{l}\text { Aspect of collaboration } \\
\text { FM should be } \\
\text { mainstreamed within } \\
\text { organizations. }\end{array}$ & $\begin{array}{l}\text { Meng (2014), } \\
\text { Carpenter and Meehan } \\
(2002)\end{array}$ & 2 & 11 \\
\hline 10 & $\begin{array}{l}\text { Involvement of senior } \\
\text { management personnel }\end{array}$ & $\begin{array}{l}\text { Collins and Junghans } \\
\text { (2015), } \\
\text { Olaniyi and Smith } \\
\text { (2014), Elmualim et al. } \\
\text { (2012a), }\end{array}$ & 3 & 16 \\
\hline 11 & $\begin{array}{l}\text { Empower regulatory } \\
\text { agencies to enforce and } \\
\text { strengthen existing } \\
\text { regulations on sustainable } \\
\text { working practices }\end{array}$ & Ikediashi et al. (2012) & 1 & 5 \\
\hline 12 & $\begin{array}{l}\text { Create awareness of } \\
\text { sustainability in general } \\
\text { and sustainable FM } \\
\text { practice }\end{array}$ & $\begin{array}{l}\text { Ikediashi et al. (2012), } \\
\text { Meng (2014) }\end{array}$ & 2 & 11 \\
\hline
\end{tabular}


INTERNATIONAL JOURNAL OF ACADEMIC RESEARCH IN BUSINESS AND SOCIAL SCIENCES Vol. 8, No. 7, July 2018, E-ISSN: 2222-6990 @ 2018 HRMARS

\begin{tabular}{|c|c|c|c|c|}
\hline 13 & $\begin{array}{l}\text { Organisations should } \\
\text { provide training and } \\
\text { practical management } \\
\text { tools for facilities } \\
\text { managers }\end{array}$ & $\begin{array}{l}\text { Baaki et al. (2016), } \\
\text { Ikediashi et al. (2014), } \\
\text { Muin et al. (2016) }\end{array}$ & 3 & 16 \\
\hline 14 & $\begin{array}{l}\text { FM organizations establish } \\
\text { better corporate images }\end{array}$ & $\begin{array}{l}\text { Tsai et al. (2014), } \\
\text { Ikediashi et al. (2012), }\end{array}$ & 2 & 11 \\
\hline 15 & $\begin{array}{l}\text { User integration } \\
\text { collaborative approach } \\
\text { between FM and } \\
\text { customer- or user- } \\
\text { oriented practice }\end{array}$ & $\begin{array}{l}\text { Buser (2017), Collins } \\
\text { and Junghans (2015) }\end{array}$ & 2 & 11 \\
\hline 16 & $\begin{array}{l}\text { Financial return, } \\
\text { investment drive and life- } \\
\text { cycle cost reduction are } \\
\text { major drivers of economic } \\
\text { sustainability }\end{array}$ & Ikediashi et al. (2014) & 1 & 5 \\
\hline 17 & Team work & Muin et al. (2016) & 1 & 5 \\
\hline 18 & $\begin{array}{l}\text { Sustainable purchasing } \\
\text { program }\end{array}$ & Kertesz (2016) & 1 & 5 \\
\hline 19 & $\begin{array}{l}\text { Sustainable/green } \\
\text { procurement }\end{array}$ & $\begin{array}{l}\text { Chin (2014), Mc Murry } \\
\text { (2014) }\end{array}$ & 2 & 11 \\
\hline
\end{tabular}


INTERNATIONAL JOURNAL OF ACADEMIC RESEARCH IN BUSINESS AND SOCIAL SCIENCES Vol. 8, No. 7, July 2018, E-ISSN: 2222-6990 @ 2018 HRMARS

From the frequency analysis as detailed in Table 2, CSF4 (i.e. strict legislation set by the government) is found to be the most dominant factor. The factor has the highest frequency, as it has been acknowledged by 6 articles (32\%) considered in this study. A part from government legislation, 4 articles (21\%) emphasized that CSF3 (i.e organization's sustainability policy) is also important to have it in order to derive sustainability in facilities management.CSF7 (i.e. the commitment and the perception of practicing facilities manager), CSF10 (i.e. involvement of senior management personnel) and CSF13 (i.e. organisations should provide training and practical management tools for facilities managers) are also crucial in achieving sustainability.

\section{Conclusion}

The study was aimed to identify success factors associated with the implementation of SFM. After analyzing various research publications, the study was able to determine 19 success factors/drivers that influence SFM. The most common identified success factors in the literature are "Strict legislation set by the government" and follow by the need to have "Organization's sustainability policy", "The commitment and the perception of practicing facilities manager", "Involvement of senior management personnel", "Organisations should provide training and practical management tools for facilities managers". From the CSF list, it is pointed out that to adopt sustainability in facilities management requires a strong commitment from various parties such as government, organization management and FM profession.

\section{Future Research}

Future research needs to be conducted to gain a real perspective of sustainability in facilities management industry. The success factors that have been identified can assemble into a questionnaire and distribute among target groups who are connected with the facilities management industry. This analysis is essential as each of the identified success factors can be perceived differently by each stakeholder, regarding the severity. Therefore, a severity analysis of the identified success factors from stakeholder's perspective is recommended, in the future.

\section{References}

1. Adewunmi, Y., Omirin, M., \& Koleoso, H. (2012). Developing a sustainable approach to corporate FM in Nigeria. Facilities, 30(9/10), 350-373. https://doi.org/10.1108/02632771211235206

2. Asbollah, A. Z., Isa, N. M., \& Kamaruzzaman, S. N. (2016). Sustainability and the facilities management in Malaysia, 85, 1-5.

3. Baaki, T. K., Baharum, M. R., \& Ali, A. S. (2016). A review of sustainable facilities management knowledge and practice, 75(January), 1-10. https://doi.org/10.1051/matecconf/20166600075

4. Buser, M. (2017). Barriers To and Challenges of Sustainable Facilities Management Practices - Experiences From the Nordic, (2005).

5. Carpenter, D., \& Meehan, B. (2002). Mainstreaming environmental management: Case studies from Australasian universities. International Journal of Sustainability in Higher Education, 3(1), 19-37. https://doi.org/10.1108/14676370210414155

6. Chin, K. V. (2014). Challenges And Awareness On Sustainable Procurement In The Context Of Facilities Management . A Dissertation submitted in part fulfilment of the Degree of Master 
INTERNATIONAL JOURNAL OF ACADEMIC RESEARCH IN BUSINESS AND SOCIAL SCIENCES

Vol. 8, No. 7, July 2018, E-ISSN: 2222-6990 @ 2018 HRMARS

of Science in Facility and Environment Management Institute of Environmental Design and Engi, (August).

7. Collins, D., \& Junghans, A. (2015). Sustainable Facilities Management and Green Leasing: The Company Strategic Approach. Procedia Economics and Finance, 21(2212), 128-136. https://doi.org/10.1016/S22125671(15)00159-8

8. Elmualim, A., Czwakiel, A., Valle, R., Ludlow, G., \& Shah, S. (2009). The practice of sustainable facilities management: Design sentiments and the knowledge chasm. Architectural Engineering and Design Management, 5(1-2), 91-102. https://doi.org/10.3763/aedm.2009.0909

9. Elmualim, A., Shockley, D., Valle, R., Ludlow, G., \& Shah, S. (2010). Barriers and commitment of facilities management profession to the sustainability agenda. Building and Environment, 45(1), 58-64. https://doi.org/10.1016/j.buildenv.2009.05.002

10. Elmualim, A., Valle, R., \& Kwawu, W. (2012a). Discerning policy and drivers for sustainable facilities management practice. International Journal of Sustainable Built Environment, 1(1), 16-25. https://doi.org/10.1016/j.ijsbe.2012.03.001

11. Escrivá-Escrivá, G. (2011). Basic actions to improve energy efficiency in commercial buildings in operation. Energy and Buildings, 43(11), 3106-3111. https://doi.org/10.1016/j.enbuild.2011.08.006

12. Ikediashi, Dubem, I., Ogunlana, S. O., \& Ujene, Anthony, O. (2014). An investigation on policy direction and drivers for sustainable facilities management practice in Nigeria. Facilities Management, Vol. 12(Issue: 3), pp.303-322. https://doi.org/https://doi.org/10.1108/JFM-022013-0013

13. Ikediashi, D. I., Ogunlana, S. O., Oladokun, M. G., \& Adewuyi, T. (2012). Assessing the level of commitment and barriers to sustainable facilities management practice: A case of Nigeria. International Journal of Sustainable Built Environment, 1(2), 167-176. https://doi.org/10.1016/j.ijsbe.2013.06.002

14. Jensen, P. A., \& Maslesa, E. (2015). Value-based building renovation - A tool for decisionmaking and evaluation. Building and Environment, 92, 1-9. https://doi.org/10.1016/j.buildenv.2015.04.008

15. Junghans, A. (2011). State of the Art in Sustainable Facility Management. 5th Nordic Conference on Construction Economics and Organisation, 553-564.

16. Store-Valen, M., \& Jardar Lohne. (2016). Analysis of assessment methodologies suitable for building performance. Facilities, 10(2), 1-2. Retrieved from http://added-value.org/overviewof-added-value

17. Kamaruzzaman, S. N., \& Zawawi, E. M. A. (2010). Development of facilities management in Malaysia. Journal of Facilities Management, 8(1), 75-81. https://doi.org/10.1108/14725961011019094

18. Kertesz, J. (2016). Sustainable Procurement for FM. Retrieved from http://fmj.ifma.org/display_article.php?id=2372303\&view=287706

19. Meng, X. (2014). The role of facilities managers in sustainable practice in the UK and Ireland. Smart and Sustainable Built Environment, 3(1), 23-34. https://doi.org/10.1108/SASBE-032013-0012 
INTERNATIONAL JOURNAL OF ACADEMIC RESEARCH IN BUSINESS AND SOCIAL SCIENCES

Vol. 8, No. 7, July 2018, E-ISSN: 2222-6990 @ 2018 HRMARS

20. Mark Vidler (2011) Why sustainability is now a must in facilities management. Retrieved from http://www.modbs.co.uk/news/printpage.php/aid/8862/Why_sustainability_is_now_a_mu st_in_facilities_management.html

21. McMurray, A. J., Islam, M. M., Siwar, C., \& Fien, J. (2014). Sustainable procurement in Malaysian organizations: Practices, barriers and opportunities. Journal of Purchasing and Supply Management, 20(3), 195-207. https://doi.org/10.1016/j.pursup.2014.02.005

22. Muin, Z. A., Sapri, M., Sipan, I., \& Adjei-Twum, A. (2016). Key Drivers of Sustainable Facilities Management (Fm) Practice for Mosques in Malaysia. International Journal of Real Estate Studies, 10(1).

23. Nousiainen, M., \& Junnila, S. (2008). End-user requirements for green facility management. Journal of Facilities Management, 6(4), 266-278. https://doi.org/10.1108/14725960810908136

24. Olaniyi, O. O., \& Smith, A. (2014). Facilities Management Approach For Achieving Sustainability in Commercial Buildings in Nigeria (Wced 1987), 1-7.

25. Rockart, J. F. (1982). The changing role of the information systems executive: A critical success factors perspective. Sloan School of Management, 3-13. Retrieved from http://dspace.mit.edu/bitstream/handle/1721.1/2010/SWP-1297-08770929-CISR085.pdf?sequence=1

26. Shah, S. (2007). Sustainable Practices for Facilities Manager. Blackwell Publishing. Oxford, UK.

27. Suzuki, M., \& Oka, T. (1998). Estimation of life cycle energy consumption and CO2 emission of office buildings in Japan. Energy and Buildings, 28(1), 33-41. https://doi.org/10.1016/S03787788(98)00010-3

28. Tsai, M.-H., Mom, M., \& Hsieh, S.-H. (2014). Developing critical success factors for the assessment of BIM technology adoption: part I. Methodology and survey. Journal of the Chinese Institute of Engineers. https://doi.org/10.1080/02533839.2014.888811.

29. WCED (1987). Our Common Future (Brundtland Report). World Commission on Environment and Development. Oxford University Press, Oxford, UK. 